\title{
MODERN INFORMATION TECHNOLOGIES IN THE CONTROL SYSTEMS FOR COMPLEX BIOTECHNICAL OBJECTS OF AGRICULTURAL APPOINTMENT
}

\author{
V.P. Lysenko, V.V. Koval, K.V. Nakonechna, D.O. Kalian \\ National University of Life and Environmental Sciences of Ukraine, Kiev, Ukraine
}

Background. In modern world, the tasks of forming appropriate control strategies for various biotechnical objects of agricultural purpose are aimed at minimizing energy costs. Traditional control systems for complex biotechnical objects in conditions of high energy costs are inefficient. It is proposed to develop energy-efficient intelligent control systems using, as a criterion of efficiency, enterprise profits and modern information technologies.

Objective. The aim of the paper is the creation of energy efficient intelligent control systems based on the analysis of natural disturbances, biological component states, price policy, continuous monitoring of the power grid equipment operation mode parameters' stability.

Methods. The analysis of existing traditional control systems for complex biotechnical objects in conditions of high energy cost made it possible to identify effective solutions for improving the reliability of integrated power supply systems for the agro-industrial complex and developing energy-efficient control systems for complex biotechnical objects.

Results. The solution to the problem of minimizing energy costs has been obtained, which contributes to an increase in the production profit in general, due to the formation of appropriate control strategies for electrical facilities that are components of technological equipment.

Conclusions. The modern theory of automatic control makes it possible to develop, using information technologies, energy-efficient control systems for complex biotechnical objects on the basis of analysis of natural disturbances, states of the biological component, price policy in the market of marketable products, and continuous monitoring of the power network equipment operation mode parameters' stability.

Keywords: automatic; infocommunication; energy efficiency; electrotechnics; control; synchronization; monitoring.

\section{INTRODUCTION}

Technological premises with biological content (animals or plants) are ascribed to complex biotechnical facilities: poultry yards and closed-ground constructions (greenhouses and boxes for mushrooms growing). Provision of the technological requirements for the biological content demands use of high capacity and power energy flows which are generally based on natural gas and electricity. Thus, portion of electricity in the prime cost of the poultry products is almost $20 \%$. As to plant products produced in glassed greenhouses, this portion rises to $80 \%$. Currently, while energy cost is growing, manufacturers do their best to minimize energy consumption which provides for raising profit of the production in whole. The task is realized by forming appropriate strategies of electrotechnical complexes control, the latter being constituent parts of the process equipment.

In order to provide necessary performance of electrical power and durability of the power supply of the elec- trotechnical complexes the power supply network should meet all the requirements for energy efficient and saving energy system functioning due to coordinated control using state-of-the-art informational technologies. Perspective ones are the studies intended for the development of innovation means for raising energy efficiency of the integrated power supply systems of the agroindustrial complex based on Smart technologies by their high durability provision with reference signal which time propagation is planned to be realized with integrated national synchro-informational system using IP technologies.

\section{STATE-OF-THE-ART CONTROL SYSTEMS AT BIOTECHNICAL FACILITIES OF AGRICULTURAL DESIGNATION}

Conventional control systems even at state-of-the-art biotechnical facilities of agricultural designation realize the simplest stabilization algorithms which keep techno- 
logical parameters at levels determined by biologists with the aid of special rooms (zootrons or phytotrons). But such systems become inefficient under conditions of high energy cost [1] as profit is generally considered an efficiency criterion of any production at the current time. Therefore, control systems should provide its maximization.

We propose to realize formation of the control strategies for the industrial poultry yards using the nonlinear programming method i.e. the one of indeterminate Lagrange multipliers [2].

$$
F\left(x_{1}, \ldots, x_{n}\right) \rightarrow \text { extr },
$$

where $F\left(x_{1}, \ldots, x_{n}\right)$ - is function (can be linear one) being explored for its extremum; and; $x_{1}, \ldots, x_{n}$ - are arguments to influence the extremum.

Lagrange theory foresees availability of some boundary conditions including nonlinear ones as follows:

$$
\begin{aligned}
& q_{i}\left(x_{1}, \ldots, x_{m}\right)=a_{i}, i=\overline{1, m}, \\
& f_{j}\left(x_{1}, \ldots, x_{n}\right) \leq b_{i}, j=\overline{1, n} .
\end{aligned}
$$

The problem related to conditional extremum of the goal function of $F(x)$ is reduced to the determination of the stationary points of Lagrange function from the following system of equations:

$$
\Phi(x, \lambda)=F(x)+\sum_{i=1}^{m} \lambda_{i}\left[q_{i}\left(x_{1}, \ldots, x_{m}\right)-a_{i}\right]+\sum_{j=1}^{n} \lambda_{j}\left[f_{j}\left(x_{1}, \ldots, x_{n}\right)-b_{j}\right] .
$$

This method foresees availability of some dependency of profit from the production on the technological parameters, first of all air temperature and humidity within the poultry yard and price policy at the market of commodity products:

$$
\left\{\begin{array}{l}
\frac{\partial \Phi(\mathrm{x}, \lambda)}{\partial \mathrm{x}_{\mathrm{i}}}=0, \\
\frac{\partial \Phi(\mathrm{x}, \lambda)}{\partial \lambda_{\mathrm{i}}}=f_{j}\left(x_{1}, \ldots, x_{n}\right)-b_{j}=0, \\
\frac{\partial \Phi(\mathrm{x}, \lambda)}{\partial \mathrm{x}_{\mathrm{i}}}=q_{i}\left(x_{1}, \ldots, x_{m}\right)-a_{i}=0 .
\end{array}\right.
$$

This method foresees availability of some dependency of profit from the production on the technological parameters, first of all air temperature and humidity within the poultry yard and price policy at the market of commodity products.

$$
\left\{\begin{array}{l}
\mathrm{P}=\mathrm{N} \cdot \mathrm{Pr} \cdot \mathrm{Y}-\mathrm{E}_{\mathrm{T}}-\mathrm{E}_{\mathrm{B}} \rightarrow \max , \\
\mathrm{Y}=\mathrm{A}_{0}+\mathrm{A}_{1}\left(\mathrm{t}-\mathrm{t}_{0}\right)^{2}+\mathrm{A}_{2}\left(\boldsymbol{\theta}-\theta_{0}\right)^{2}+\mathrm{A}_{3}\left(\mathrm{~B}-\mathrm{B}_{0}\right)^{2}+\mathrm{A}_{4}\left(\mathrm{~K}-\mathrm{K}_{0}\right)^{2}+ \\
+\mathrm{A}_{5} \cdot \boldsymbol{\theta} \cdot \mathrm{B}+\mathrm{A}_{6} \cdot \theta \cdot \mathrm{K}, \\
\mathrm{Y}>\mathrm{Y}_{\text {мін }}, \mathrm{K}<0,18, \mathrm{E}_{\mathrm{m}} \geq 0,
\end{array}\right.
$$

where $Y$ - is egg production of poultry, pcs./head; $t-$ is poultry age, days; $\theta$ - is air temperature within the poultry yard, ${ }^{\circ} \mathrm{C} ; B-$ is relative humidity within the poultry yard, $\% ; K-$ is carbon dioxide concentration in the air of the poultry yard, \%; $N$ - is number of poultry in the poultry yard, head; $L_{B}-$ is amount of the ventilated air, $\mathrm{m}^{3} / \mathrm{h}$; $E_{T}-$ is costs for the poultry heating, UAH/day; $E_{B}-$ is costs for the poultry ventilation, UAH/day; $\mathrm{Pr}-$ is selling price of eggs, UAH/pc.; $A_{0}-A_{6}, t_{0}, \theta_{0}, B_{0}$ and $K_{0}-$ are parameters of the mathematical model.
Solution for the optimization problem is carried out according to the algorithm described in [2].

Such the system was realized as an automated one and showed significant advantages compared to conventional ones.

Optimization of the production process at poultry factories based on Lagrange method does not take into account states of the biological contents which are greatly dependent on the air temperature within the technological room, and the latter in turn depends upon natural disturbances changed by random algorithms.

A system was developed which forms rational strategies of electrotechnical complexes control at high durability using theory of random processes, state of poultry and price policy at the commodity market based on analysis of natural disturbances and their forecasting using theory of plays and statistical solutions [3].

In this play the rows are the ones shown in Table $1, A_{i}$ - is strategy of the system control, and $\Pi j-$ is strategies of the nature (possible realization patterns of the air temperature). $a_{i j}$ - is elements of the payoff ray stand for the profit due to production of the chicken eggs which can be reached when applying $A_{i}$ control strategy when realizing $\Pi_{j}$ natural strategy. Values of $a_{i j}$ within the submitted system are determined by the following formula:

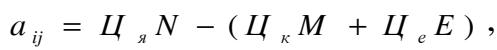

Elements of the payoff array of playing with nature are calculated based on values of products, energy carriers, concentrated forages and biological content (egg production and forages consumption).

Table 1. Payoff ray for playing with nature (for the subsystem of making managerial solutions)

\begin{tabular}{|c|c|c|c|c|}
\hline \multirow{2}{*}{$\mathrm{A}_{\mathrm{i}}$} & \multicolumn{4}{|c|}{$\Pi_{\mathrm{j}}$} \\
\cline { 2 - 5 } & $\Pi_{1}$ & $\Pi_{2}$ & $\ldots$ & $\Pi_{\mathrm{n}}$ \\
\hline $\mathrm{A}_{1}$ & $\mathrm{a}_{11}$ & $\mathrm{a}_{12}$ & $\ldots$ & $\mathrm{a}_{1 \mathrm{n}}$ \\
\hline $\mathrm{A}_{2}$ & $\mathrm{a}_{21}$ & $\mathrm{a}_{22}$ & $\ldots$ & $\mathrm{a}_{2 \mathrm{n}}$ \\
\hline$\ldots$ & $\ldots$ & $\ldots$ & $\ldots$ & $\ldots$ \\
\hline $\mathrm{A}_{\mathrm{m}}$ & $\mathrm{a}_{\mathrm{m} 1}$ & $\mathrm{a}_{\mathrm{m} 2}$ & $\ldots$ & $\mathrm{a}_{\mathrm{mn}}$ \\
\hline
\end{tabular}

Natural disturbances of the forecast class are reproduced with certain statistical extent using method of forming filters. Three of the ten possible realization scenarios are chosen accepted for the natural strategy. Five control strategies are used in order to compensate for the natural strategies.

Choice of optimum control strategy is realized by analyzing payoff array using Hurvitz criterion which provides making averaged weighted profit at low risks on the assumption of the following condition:

$$
H u=\max _{\mathrm{i}}\left(\chi \max _{\mathrm{j}} a_{i j}+(1-\chi) \min _{\mathrm{j}} a_{i j}\right),
$$

where $\chi$-optimism factor which can take values from 0 to 1 .

If $\chi=0$ the criterion is reduced to Wald criterion of extreme pessimism (principle of caution and playing safe), but if $\chi=1$ the criterion converts into maximum criterion of absolute optimism. Rather high forecasting accuracy as well as reproduction of the pictures of the thermal dis- 
turbances (natural strategies) take place even at initial stage of the recognition algorithm; high poultry ability to adapt to the environment having been revealed gives reasons to ascribe optimism factor values higher than 0.5 . In other words, we can expect successful result of making appropriate solution with confidence. Value of $\chi=0,75$ is accepted in the proposed control system. Efficiency of such the solution was confirmed by numerous experimental studies of the control system under production conditions. Raising this factor to 0.8 as well as its lowering to less than 0.7 leads to loss increase because of choosing less efficient control strategies at ca. $10 \%$ cases during entire period of poultry keeping.

\section{CONTROL SYSTEM USING ARTIFICIAL NEURON NETWORKS AND ISOLATION OF USEFUL SIGNAL}

Unlike poultry keeping rooms, closed-ground constructions with plants are influenced with solar radiation in addition to ambient temperature, the former influences atmosphere parameters and state of the plants inside the greenhouse. A system was developed within which forecasting of these factors was realized using artificial neurons networks and isolation of useful signal based on Hilbert - Huang algorithm (Fig. 1).

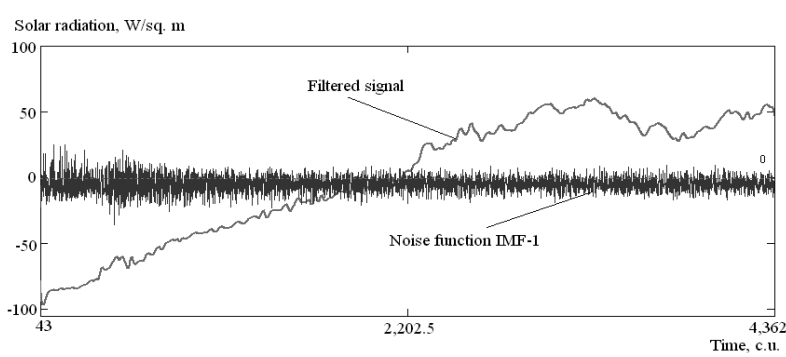

Fig. 1. Results of the solar radiation intensity time row filtration using Hilbert - Huang algorithm are used as weighing factors

As already noted, profit of an enterprise is frequently used as efficiency criterion in case of energy efficient systems. The above is the most significant in case of closed-ground constructions where portion of the energy value in the structure of the initial price sometimes equals $80 \%$. Quality of the products grown and power consumption influencing the profit substantially (in case of manufacturing planned quantity of the products), Harington method is used for the approval of these criteria provided that quality of plant products is the feedback in such a system is as follows [4]:

$F\left(Я\left(\Theta_{p}, \Theta_{\Pi}, \varphi\right), B\left(\Theta_{p}, \Theta_{\Pi}, \varphi\right)\right)=\left(Я\left(\Theta_{p}, \Theta_{\Pi}, \varphi\right)\right)^{0.5} *\left(B\left(\Theta_{p}\right.\right.$, $\left.\left.\Theta_{\Pi,}, \varphi\right)\right)^{0.5} \rightarrow \max ,(8)$

$$
Я\left(\Theta_{p}, \Theta_{\Pi}, \varphi\right) \rightarrow \max , B\left(\Theta_{p}, \Theta_{\Pi}, \varphi\right) \rightarrow \min ,
$$

where $Я\left(\Theta p, \Theta_{\Pi}, \varphi\right)$ stands for the quality of plant products influenced by plant temperature $\Theta_{p}$ and air temperature and humidity $\left(\Theta_{\Pi}\right.$ and $\varphi$, respectively). Index of 0.5 is used as weighing factor.

A system for control of biotechnological facility was developed according to the research results (Fig. 2) which consists of subsystem for making solutions 1 (consists of filtration unit of the input signal 2 , unit for neuron network forecast of the product quality 3, neuron network unit for the profit estimation 4 , decision making unit 5 , and control unit 6 ), mobile robot unit for the monitoring of production parameters 7 , and local control system 8 (consists of local automatic control device 9 , executive elements 10 and control unit 11).

Maximum profit in the production is made in case that the plant temperature equals $21.3^{\circ} \mathrm{C}$, air temperature equals $22.5^{\circ} \mathrm{C}$, and air humidity equals $60 \%$. At such production the quality indices within the limits of "very well" are reached at minimum energy consumption.

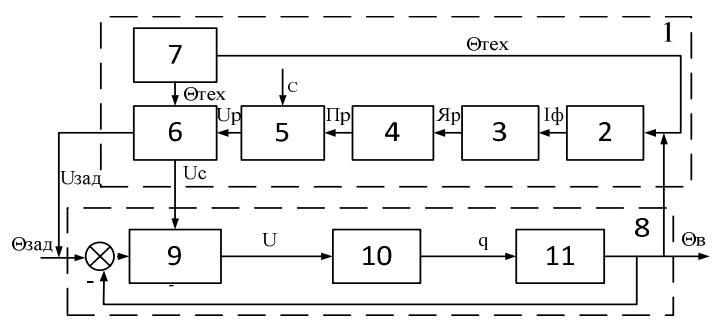

Fig. 2. Functional diagram of control of growing high quality plant products to maximize profit

\section{SYNCHRO-INFORMATIONAL SYSTEM OF ENERGY EFFICIENT INTEGRATED POWER SUPPLY NETWORKS OF THE AGRO-INDUSTRIAL COMPLEX}

Modern energy facilities of the agro-industrial complex demand reliable provision of bidirectional flow of electric power and entire necessary data between appropriate elements i.e. power plants, sources, and accumulators for electric power as well as its consumers. Existence of the system for the distributed generation demands development of new principles for designing, functioning and control of the functioning modes. When distributive electrical networks, containing dispersed power sources (wind, solar and other poser stations consuming non-traditional energy sources), perform a number of tasks for managing working modes, durability as well as organization of functioning of the automation, controlling, monitoring and telecommunications systems. These tasks are related directly with the informatization of the integrated systems of electric power supply as control systems and the ones for monitoring equipment parameters.

In order to ensure approipriate quality performance of electric power and durability of the electric power supply the network should meet all the requiremets for the energy efficient and saving functioning of the energy system due to coordinated control using state-of-the-art informational technologies. Raising energy efficency of integrated electric power supply systems of the agro-industrial complex based on Smart technologies is possible due to durable provision with high quality national time scale for the purpose of uninterrupted stability of the parame- 
ters of the functioning modes of the equipment of the electric power networks accurate to microsecond.

Some technical means available in Ukraine which form and keep national time scale at the same level as the best national ones in the world do not create any integrated informational system for the distribution of the national time scale and cannot meet demands of the consumers of frequency and time data not only in power engineering but within other sectors of economics [5]. This makes consumers use synchronized information from other states (GPS, GLONASS, GALILEO, BEIDOU) which poses a threat to national security and increases risks of losing unity of measuring time and frequency within the state. Principal drawbacks of such satellite systems are dependency of the radio signal quality on non-stationary parameters of open propagation space as well as unavailability of durable data securing from intentional distortion.

It was revealed based on the results of the analysis of today's market of synchronized information which is characterized with deficiency of offers that introduction of some technical solutions for provision with the national time scale of various consumers from individual (point or unit) to collective ones (clusters, networks or systems) individually or even at regional level is of low efficiency. Such the problem requires solution on the governmental level by the creation of ntegrated National Synchroinformational System (INSS) to allow raising quality and efficiency of provision of a wide circle of consumers with synchronized information frst of all due to integration of the processes of rendeering these services.

Classification of the means for the transmission of the reference signals of time and frequency and time scale within the state was presented, and dominating factors to substantiate conceptual grounds of the INSS arrangement were determined. It was revealed by results of the experimental studies of the systems of synchronization of digital telecommunications that synchronized information can be distributed by telecommunication networks with synchronous digital hierarchy at sufficiently high accuracy (unities to hundreds of nanoseconds). It should be noted that technologies of asynchronous data transmission with packets commutation (IP technologies) are introduced actively within the informational infrastructures bearing in mind growing demand for Internert services and multimedia data transmission. Some new innovation means for the synchronized information transmission using IP technologies based on Presision time protocol PTP (IEEE-1588v2) are proposed in order to solve the problems related to raising energy efficiency of integrated power supply systems of agro-industrial complex.

A laboratory test bench was developed and some experimental studies of a number of synchronization devices were conducted that are parts of the informational system fragment for the national time scale distribution developed based on the corporative IP network of the National University of Life and Environmental Sciences of Ukraine. Results of the experimental studies of time characteristics of precision time signals of PTP (IEEE1588v2) protocol emitted by US-1588M and US$1588 \mathrm{~S}$ devices manufactured domestically are shown on Fig. 3 (measuring interval equals two days). Analysis of the study results for their conformity to International recommendations of G.810 and G.8262 allows approving the requirements for the regulations by MTIE quality performance for the two-days measuring interval.

The results derived in the process of the complex studies testify posibility of the transmission of time signals using functioning IP networks [5].

A competitive synchronization device with adaptive digital phase discriminator (patent for invention No. 113473 of Ukraine) is developed to provide speedsensitive modes of transient regimes and precision capabilities in the "holdover" mode.

The testing was performed on the active IP network of the adaptive synchronization device (ASD) as part of synchronization information digital transmission system. During the testing, a set of ASD output signal measurements, which is connected to the active IP network as part of synchroinformation digital transfer system, is carried out. The result of the output signal time interval (TIE) deviation measurements of the adaptive device for synchronization device ASD connected to the active IPnetwork is shown in Fig. 4.

Based on the measurement results, statistical processing of the obtained data was performed and a comparison of the standardized indicators with the corresponding reference values was done.

The results of statistical processing of the measurements of the output signal of the ASD connected to the active IP network and the comparison with the MTIE and TDEV reference values of the ETS 300 464-4 standard are shown on Fig. 5, and Fig. 6, respectively.

Analysis of the results of statistical processing of measurements of the output signal of ASD connected to the active IP network for compliance with the standards of the European standard ETS 300 464-4 allows us to conclude the compliance with the standards for MTIE and TDEV indicators.

Recommendations for the development of integrated informational system for the distribution of the national time scale based on Presision time protocol PTP and adaptive synchronization devices optimal by aggregate of their performance as well as high tech equipment produced mainly domestically which can be the basis for the active realization of the integrated synchroinformational system were developed as result of the research.

The mentioned research provides possibility of applied substantiation of the conduction of proper studies intended for the development of some innovative devices for raising efficiency of integrated power supply systems of the agro-industrial complex based on Smart technologies due to durable provision with high quality national time scale for the uninterrupted monitoring of the stability of the functioning parameters of the equipment of the power supply networks accurate to microsecond. 


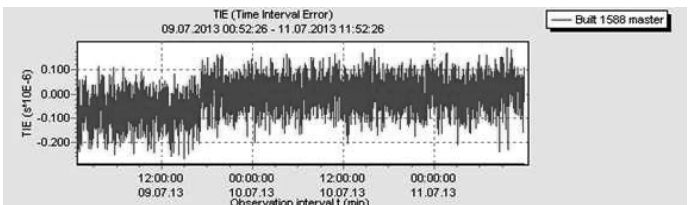

Fig. 3. Results of the studies of US-1588S equipment manufactured domestically

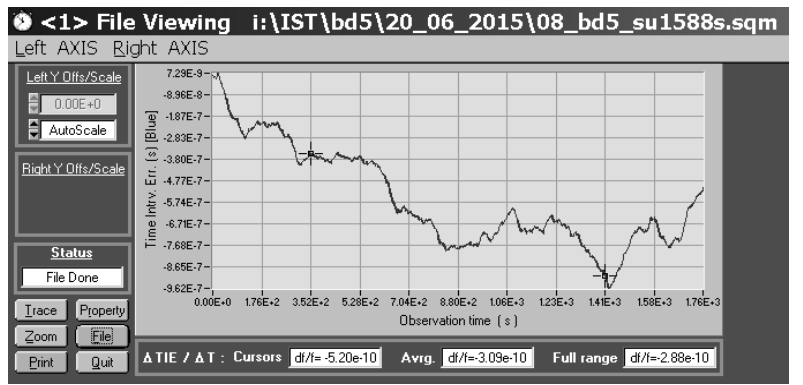

Fig. 4. The result of measuring time interval error (TIE) of the output signal of ASD connected to an active IP network

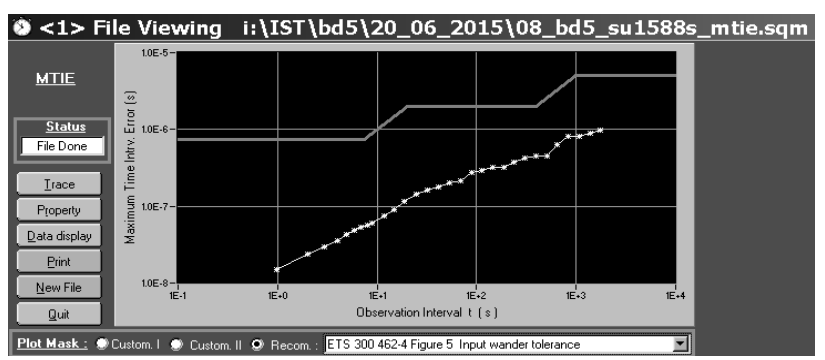

Fig. 5. The results of statistical processing of the measurements of the output signal of ASD connected to the active IP network and comparison to MTIE reference value of ETS 300 464-4 standard

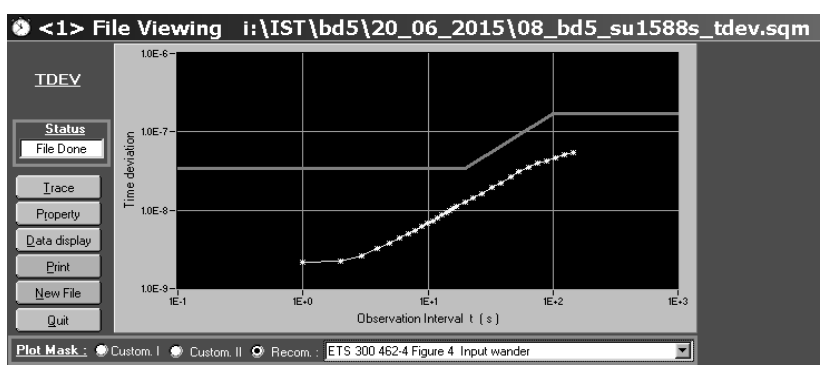

Fig. 6. Results of statistical processing of measurements of the output signal of ASD connected to an active IP network and comparison to TDEV reference values of ETS 300 464-4 standard

The results of the system and analytical studies obtained are to provide possibility of innovational introduction of technical solutions intended for the development of integrated national synchro-informational system of Ukraine (INSS), and it should be the basis for the effective solution of the national problem related to the application of the unified (by Kyiv) accounting and reporting time by consumers through the entire territory of the state. Solution of the mentioned problem at the national level is to create conditions firstly for raising informational security of the consumers and secondly for raising competitiveness at the market due to efficient integrated rendering services for both governmental structures including law inforcement and corporative consumers. According to practice facilities of a number of spheres of the economics and critical governmental infrastructure should be provided with unified reference signals of the national time scale through the introduction of the results of the research; hence, national informational security is to raise due to transmission of data from the national reference sources alternative to foreign global navigation satellite systems.

\section{Conclusions}

1. Conventional control systems for complex biotechnical facilities realizing the simplest stabilization regimes are inefficient under conditions of high value of power.

2. Efficiency criterion for the vast majority of the agricultural enterprises under conditions of high values of energy carriers is profit.

3. Raising efficiency of integrated power supply systems of the agro-industrial complex is possible by creating integrated informational system for the distribution of the national time scale using IP networks and high durability transfer of synchronized information from the domestic reference sources.

4. Up-to-date theory of automatic control allows developing energy efficient control systems for complex biotechnical facilities based on analysis of natural disturbances, states of the biological constituent part, price policy at the market of commodity products, and uninterrupted monitoring of the stability of the functioning parameters of the equipment of power networks.

\section{References}

1. Lysenko V.P. Analysis of traditional climate control systems for poultry houses. Ways to reduce energy costs and improve the efficiency of egg production in the poultry factories / V.P. Lysenko, B.L. Golovinsky, N.A. Rusynyak // Scientific Bulletin of the National Agrarian University. - 2008. - No. 118. - P. 174-181.

2. Lysenko V.P. The use of the Lagrange method to determine the optimal microclimate parameters in an industrial poultry house. V.P. Lysenko, N.A. Rusynyak // Electrification and Automation of Agriculture. - 2004. - No. 2 (7). - P. 7583.

3. Lysenko V. Dynamics of quality indexes of layinghenskeeping process duet of luctuations of temperature disturbancesinan industrial poultry house / Vitaliy Lysenko, Boris Golovinskiy, Vladimir Reshetyuk, Bella Golub, Vadim Shcherbatyuk // Annals of Warsaw University of Life Sciences - SGGW. - 2011. - № 57. - P. 79-92.

4. Lysenko V.P., Bolbot I.M., Lendel T.I., Chernov I.I. Biotechnical object management system. Patent for utility model № 103274. Registered in the State Register of Patents of Ukraine for Utility Models 10.12.2015. 
5. Development of the concept of scientific and applied foundations for the creation of a unified information system for the dissemination of the national time scale with the use of IP technologies: Report on research on state order/NUBiP of Ukraine; the state registration number: 0115U003376. - M., 2016. - 172p.

Лисенко В.П., Коваль В.В., Наконечна К.В., Кальян Д.О.

Сучасні інформаційні технології в системах керування складними біотехнічними об'єктами аграрного призначення

Проблематика. В умовах сьогодення задачі формування відповідних стратегій керування різноманітними біотехнічними об'єктами аграрного призначення направлені на мінімізацію енергетичних витрат. Традиційні системи керування складними біотехнічними об’єктами в умовах високої вартості енергії є неефективними. Пропонується розробляти енергоефективні інтелектуальні системи керування з використанням в якості критерію ефективності прибутку підприємства та сучасних інформаційних технологій.

Мета досліджень. Створення енергоефективних інтелектуальних систем керування на основі аналізу природних збурень, станів біологічної складової, цінової політики, безперервного моніторингу стабільності параметрів режимів функціонування обладнання електроенергетичних мереж.

Методика реалізації. Аналіз діючих традиційних систем керування складними біотехнічними об'єктами в умовах високої вартості енергії дав змогу виявити ефективні рішення щодо підвищення надійності інтегрованих систем електропостачання агропромислового комплексу та розробки енергоефективних систем керування складними біотехнічними об'єктами.

Результати досліджень. Отримано рішення задачі мінімізації енергетичних витрат, що сприяє збільшенню прибутку виробництва в цілому, за рахунок формуванням відповідних стратегій керування електротехнічними комплексами, що є складовими технологічного обладнання.

Висновки. Сучасна теорія автоматичного керування дозволяє розробляти з використанням інформаційних технологій енергоефективні системи керування складними біотехнічними об'єктами на основі аналізу природних збурень, станів біологічної складової, цінової політики на ринку товарної продукції, безперервного моніторингу стабільності параметрів режимів функціонування обладнання електроенергетичних мереж.

Ключові слова: автоматика; інформаційні технології; енергоефективність; електротехніка; керування; синхронізація; моніторинг

Лисенко В.Ф., Коваль В.В., Наконечная К.В., Кальян Д.А.

Современные информационные технологии в системах управления сложными биотехническими объектами аграрного назначения

Проблематика. В современных условиях задачи формирования соответствующих стратегий управления различными биотехническими объектами аграрного назначения направлены на минимизацию энергетических затрат. Традиционные системы управления сложными биотехническими объектами в условиях высокой стоимости энергии являются неэффективными. Предлагается разрабатывать энергоэффективные интеллектуальные системы управления с использованием, в качестве критерия эффективности, прибыли предприятия и современных информационных технологий.

Цель исследований. Создание энергоэффективных интеллектуальных систем управления на основе анализа природных возмущений, состояний биологической составляющей, ценовой политики, непрерывного мониторинга стабильности параметров режимов работы оборудования электроэнергетических сетей.

Методика реализации. Анализ действующих традиционных систем управления сложными биотехническими объектами в условиях высокой стоимости энергии позволил выявить эффективные решения по повышению надежности интегрированных систем электроснабжения агропромышленного комплекса и разработки энергоэффективных систем управления сложными биотехническими объектами.

Результаты исследований. Получено решение задачи минимизации энергетических затрат, которое способствует увеличению прибыли производства в целом, за счет формирования соответствующих стратегий управления электротехническими комплексами, которые являются составными частями технологического оборудования.

Выводы. Современная теория автоматического управления позволяет разрабатывать с использованием информационных технологий энергоэффективные системы управления сложными биотехническими объектами на основе анализа природных возмущений, состояний биологической составляющей, ценовой политики на рынке товарной продукции, непрерывного мониторинга стабильности параметров режимов работы оборудования электроэнергетических сетей.

Ключевые слова: автоматика; информационные технологии; энергоэффективность; электротехника; управления; синхронизация; мониторинг. 